\title{
Healthy Young Bodies of an (Un)healthy Nation: Physical Education and Discipline in Straja Țării (1934-1940)
}

\section{Anca FILIPOVICI}

\begin{abstract}
This text discusses Straja T,ării, the Romanian youth organization patronized by King Carol II, and created in the tense social and political atmosphere of the 1930s. While reinforcing the loyalty to the king, Străjeria aimed for an integral education based on moral values, religious and patriotic feelings, and physical training. Although active for a short time, Straja was one of the main social intervention institutions, with high autonomy during the royal dictatorship, mobilizing considerable human and financial resources. It developed specific mechanisms and tools for youth control, including discipline through physical education leading to the strengthening of the young bodies. The paper analyzes the multiple functions of these mechanisms using archival documents, legislation and health surveys carried out in that epoch. The research builds on three levels of analysis: the regulation of physical education and public health in interwar Romania (1); the social control of young bodies through Straja Țării (2); the health deficiencies of the young generation (3). The main argument of this article is that Straja has built an overrated national prototype of the vitality of youth, without properly addressing the deficiencies and cleavages of a relatively healthy nation.
\end{abstract}

Keywords: youth, discipline, physical education, public health, Straja Țării, biopolitics.

\section{Straja Țării - the royal laboratory for the bright future of the nation}

We have high school kids. These children complain that they are too tired. Your Majesty, almost 6 hours of sentinel training on Thursday is too much in addition to the crowded schedule during the week [...] We are not against this beneficial education, but keep in mind that they are children of various kinds, weak, helpless, hungry and malnourished. They live in improper conditions at their hosts and in boarding schools.

I have seen children, who come so tired from high school, that they fall asleep at the table; they come back exhausted and don't even eat anymore ${ }^{1}$.

This extract is part of a complaint addressed to King Carol II in the autumn of 1938, by a group of parents of high school students from Bucharest who were

1 Arhivele Naționale Istorice Centrale (ANIC), Fund The Ministry of Education, file 622/ 1938, 294. 
also trained as străjeri [sentinels] - members of the compulsory youth organization Straja Țării [The Sentinel of the Motherland]. The petition reflects two competing political and social realities in 1930s Romania: on the one hand, the regime's vision of the young people enrolled in Straja Țării as the future strong defenders of the homeland, and on the other hand, the precarious health and overwork of a large part of the students engaged in this extracurricular training. What was the context for the development of education outside the school premises through the Străjerie?

Straja Țării followed the model of European youth policies after the First World War, with most states intervening directly in the management of the socalled new generations without ideals. The Romanian state designed social engineering mechanisms for young people of different ages, starting with the educational-cultural training from an early age and subsequently involving young adults in social work projects for raising the cultural level of Romanian villages. In 1933-1938, legislative measures were introduced targeting young people through the Law for the Royal Cultural Foundations $(1933)^{2}$, followed by the creation of the Oficiu de Educație a Tineretului Român [Romanian Youth Educa-

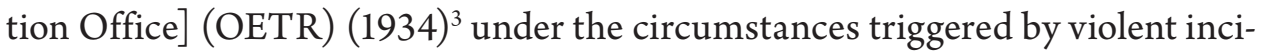
dents involving high school students. Political radicalization and the excesses of indiscipline were consequences of the social tensions of the post-war realities, which were exacerbated by the economic crisis and the rise of local fascism, represented by the Legionary Movement. In 1934, regulations were also implemented for young people aged 18-20, by establishing compulsory pre-military training, which should have developed morality, patriotism, law and order, and civic discipline ${ }^{4}$. After 1938, with the establishment of the king's dictatorship (February 10, 1938 - September 6, 1940), the other youth organizations were incorporated into Straja Țării or officially disbanded.

All these forms of mobilization worked together as tools of foreign policy, but they also represented an internal intervention with a dual purpose. Packed with a high degree of formality and military symbolism, these institutions aimed at social improvement, but also at diminishing the influence of the competing Legionary Movement on the youth, with its Brotherhoods of the Cross and work camps. Also, the organization aimed to strengthen national unity while manifesting an ambiguous and sometimes deceitful attitude towards the minority youth.

2 Lege pentru Fundațiunile Culturale Regale, Monitorul Oficial, Part I, no. 88, 14 April 1933.

3 Lege pentru înființarea Oficiului de Educație a Tineretului Român (OETR), Monitorul Oficial, Part I, no. 106, 9 May 1934.

4 Lege pentru pregătirea premilitară, Monitorul Oficial, Part I, no. 107, 11 May 1934. 
Thus, in the second half of the 1930s, the school-age youth in Romania was integrated into a mass organization outside the traditional pattern of education within the school. The youth organization created in 1934 under OETR became an autonomous institution enshrined in legislation by a decree-law in $1937^{5}$ and by a special law a year later ${ }^{6}$. Enrollment was mandatory and included all youngsters (boys aged 7-18 and girls aged 7-21). It pursued "the national and physical education of young people of both sexes" and "the coordination and control of similar activities of state and private institutions” (1934 OETR Law, art. 1). In the beginning, it used the infrastructure of the scouting movement for the training courses of the future commanders of the sentinels - mainly comprising teachers and other professional categories ${ }^{7}$. As the commanders graduated from the courses, the schools gradually introduced the sentinel program into the curriculum, allocating one day a week for practical courses and outdoor training. Starting from 1938, the organization also introduced a similar program for the working youth affiliated to Asociația Creștină a Tinerilor [the Christian Youth Association] and Asociaţia Creștină a Femeilor [the Christian Women Association]. Young people from Transylvania and Bukovina also participated in the Străjerie through the regional organizations Șoimii Carpaților [the Carpathian Hawks] and Arcașii Bucovinei [the Archers of Bukovina]. The highly propagandistic dimension was displayed especially by the participation of the sentinels in uniforms at the royal festivities of June 8 (The Youth and Restoration Day) ${ }^{8}$. These programs aimed at rearing and perfecting future disciplined citizens, attached to national, moral and religious values, with an adequate physical condition fit to defend the country and to conceive vigorous future generations.

During its relatively short existence, Straja Țării functioned as a fundamental tool for consolidating royal power and for the ideological reconfiguration of the nation's youth. Logistically and organizationally, it shared the principles of fascist-type youth organizations (especially the Opera Nazionale Balilla in Italy $^{9}$ ) but shaped its formal aspects according to local politi-

5 Decret regal. Înființarea Straja Țării, Monitorul Oficial, Part I, no. 233, 8 October 1937.

6 Lege pentru organizarea și funcționarea Străjii Țării, Monitorul Oficial, Part I, no. 292, 15 December 1938.

7 Regulament pentru organizarea și funcționarea Oficiului de Educație a Tineretului Român, Monitorul Oficial, Part I, no. 272, 24 November 1934. Scouting merged with Straja Țării in 1937, for reasons of financial economy, Cf. ANIC, Fund The Ministry of Instruction, file $571 / 1937,235$.

8 These festivities celebrated Carol's return to the country in June 1930, after a 5 years exile, and his ascending to the throne as king of Romania. Since 1936, June 8 was also designated as Youth Day.

9 See, for instance, Eden K. McLean, Mussolini's Children. Race and Elementary Education in Fascist Italy (Lincoln \& London: University of Nebraska Press, 2018). 
cal interests. By setting in motion the king's vision of control over youth, the organization expanded and gradually gained power and autonomy. A statistical survey indicates for the year 1939 over 27,000 commanders of all ranks, who guided over 3 million sentinels ${ }^{10}$. A year later, the statistics registered $4,373,039$ sentinels and 44,875 commanders $^{11}$. Straja had tried to coagulate this generation through various mechanisms that soon showed their shortcomings. However, this institution provided the future regimes with a paradigmatic model for organizing the Romanian youth.

Physical education as a generator of discipline and health of the young people was a fundamental pillar underpinning the doctrine of the sentinels. As recent research shows, the privileged status of sports and physical activity produced results that were considered valuable in themselves. However, they differed depending on the agency that designed these tools: state authorities can manage physical education to achieve educational improvements, health, regeneration, social control, discipline, patriotism etc.; for the individuals, physical activity produces values at a personal level (status, wealth, health etc.) ${ }^{12}$.

Research on physical culture opens a new perspective on the study of nation-states in the $20^{\text {th }}$ century. Romanian historiography also features several works that explore physical education, and especially sports, both as social phenomena and as national ideological and propaganda tools ${ }^{13}$. Recent research on social history and ethnography places physical culture within the debates on public health during the past centuries, viewing it as a landmark of state mod-

${ }^{10}$ Straja Țării. Romanian Youth Educational Movement (Bucharest: s.n., 1939), 25.

${ }^{11}$ C. Enescu-Bughea, „Cinci ani de activitate 1935-1940”, in Straja Țării. Cinci ani de activitate. 1935-1940 (Bucharest: Vremea, 1940), 216.

12 Cathy Devine, Hamish Telfer, "Why Are Sport and Physical Education Valuable? Values, Sport, and Physical Education”, in Values in Youth Sport and Physical Education, eds. Jean Whitehead, Hamish Telfer, John Lambert (London, New York: Routledge, 2013), 16. Modern sport is categorized according to similar criteria by the scholarly literature: sports for the sake of movement - an elitist form of competition and performance, with individual values at its core; sports of discipline and integration, as a social value; and sports as a context of socialization and relationships, with specific value for human groups. Henning Eichberg, Bodily Democracy: Towards a Philosophy of Sport for All (London, New York: Routledge, 2013).

${ }^{13}$ Bogdan Popa, Educație fizică, sport și societate în România interbelică (Cluj-Napoca: Eikon, 2013); Florin Faje, "Playing For and Against the Nation: Football in Interwar Romania", Nationalities Papers, vol. 43, no. 1 (2015): 160-177, https://doi.org/10.1080/00905992.201 4.937684; Constantin Pompiliu-Nicolae, Valentin Maier, "Sport and Physical Education in Communist Factories: From the Soviet Union to Romania”, Romanian Journal of History and International Studies, no. 2(2) (2015): 217-232; Marius Rotar, Vasile Emil Ursu, "Romanian Religious Environments and the Development of Sports in Romania in the 1930s", Sport in History (published online 16 December 2020), DOI: 10.1080/17460263.2020.1858149. 
ernization ${ }^{14}$. This article bases its approach on these conceptual models, focusing on the interwar youth and arguing that physical activity was instrumentalized by the regime of King Carol II as a factor of national regeneration, though achieving poor results in improving the health of the young people.

The paper discusses Straja Țării as a body control mechanism from two perspectives: physical education and the health of the young bodies. The significance of these elements is analyzed at the following levels: 1) legal norms and regulations, 2) the doctrine and principles of sentinel training, 3) and the grassroots view captured by public health surveys and case studies on the vitality of the young generation. The article is a segment of a broader research project on Straja Țării and is based on a rich array of primary sources. These sources include the regulation of physical education and public health, providing an overview of the evolution of the norms, but also underscoring the limited capacity of the state to solve key health and social problems. Other laws, regulations and archival documents highlight the solutions proposed by Straja Țării for social improvement and regeneration. Most documents were issued by the Ministry of Education and contain the provisions and decisions of the OETR and Straja Țării, institutional correspondence, investigation reports and petitions that allow a closer look at the organization's operation and reception from below. Finally, among the relevant sources from that era one could mention some surveys on school health and hygiene produced in the 1920s and 1930s, as well as the results of the 1938 "sanitary offensive" - a complex national survey published in four volumes regarding the assessment of and the state interventions concerning public health in Romania.

\section{Discipline in motion/Building the body of tomorrow}

Some research has identified the use of physical education in the educational discourse of $17^{\text {th }}$-century scholarly literature for children ${ }^{15}$, while in modern times, gymnastics revealed a valuable potential for the processes of national

${ }^{14}$ Constantin Bărbulescu, România medicilor. Medici, țărani și igienă rurală în România de la 1860 la 1910 (Bucharest: Humanitas, 2015); Lidia Trăușan-Matu, De la leac la rețetă. Medicalizarea societății românești în veacul al XIX-lea (1831-1869) (Bucharest: Editura Universității din București, 2011); Octavian Buda, Identitate națională și medicină socială: antropologie culturală, psihiatrie și eugenism în România: 1800-1945 (Bucharest: Muzeul Național al Literaturii Române, 2013).

${ }^{15}$ Rebekka Horlacher, "The Emergence of Physical Education as a Subject for Compulsory Schooling in the First Half of the Nineteenth Century: The Case of Phokion Heinrich Clias and Adolf Spiess", Nordic Journal of Educational History, vol. 4, no. 2 (2017): 13-30, https:// doi.org/10.36368/njedh.v4i2.93. 
unification or independence ${ }^{16}$. In the $20^{\text {th }}$ century, sports and physical education guided youth policies in most nation-states, regardless of the political regime. In the matrix of power relations between state authority and individuals, bodies became the locus of social control. Youngsters, in particular, have been drawn into historical processes through various practices and discourses that have classified and modified their bodies ${ }^{17}$. Following the ground-breaking formulations of Michel Foucault ${ }^{18}$, sports and physical activity were among the disciplinary practices through which the free, explosive energy of the juvenile body was transformed into constrained, obedient energy, directed by authorities towards meaningful and useful purposes.

In the 1930s, the social control of youth through discipline supported by physical education became state policy. An analysis of the management of youth policies worldwide showed that, in industrialized countries, youth was associated with the danger of delinquency, demoralization, and unemployment. Under these conditions, some countries tried to involve young people in activities that would keep them busy, concluding that "modern youth's difficulties have their roots in idleness" 19 . The theory of moral education developed by the French sociologist Émile Durkheim in the late $19^{\text {th }}$ century was thus still relevant during the 1930s: "when the individual activity does not know where to take hold, it turns against itself. When moral forces of society remain unemployed, they deviate from their moral sense and are used up in a morbid and harmful manner" ${ }^{20}$. Most states sought to control youth organizations through programs meant to regenerate society, with a special emphasis on physical education $^{21}$. Since 1934, Romania also followed this path, by creating the OETR

${ }^{16}$ Examples include the German Turner movement inspired by Friedrich Ludwig Jahn, in Ken Hardman, Roland Naul, "Introduction”, in Sport and Physical Education in Germany (London, New York: Routledge, 2002). On the ideological instrumentalization of physical education see also Conor Heffernan, "Marching Forwards or Backwards? Physical Education and the Army in Early Twentieth-Century Ireland”, Sport in Society, vol. 23, no. 8 (2020): 12801298, https://doi.org/10.1080/17430437.2020.1769945.

${ }^{17}$ R.W. Connell, The Men and the Boys (Sydney: Allen \& Unwin, 2000), 57-58.

${ }^{18}$ Michel Foucault, A supraveghea și a pedepsi. Nașterea închisorii (Bucharest: Humanitas, 1997).

${ }^{19}$ Youth. A World Problem. A Study in World Perspective of Youth Conditions, Movements and Programs, by W. Thacher Winslow. With a foreword by Aubrey Williams. National Youth Administration (Washington: United States Government Printing Office, 1937), 117.

${ }^{20}$ Émile Durkheim, Moral Education. A Study in the Theory and Application of the Sociology of Education (London: The Free Press, 1973), 13.

${ }^{21}$ In Bulgaria - the Bulgarian Youth Union (a national 'patriotic organization aiming to regenerate the country's moral and social life'); in Germany - Hitlerjugend (the only officially allowed youth organization); in Italy - Opera Nazionale Balilla (centered on moral and phy- 
and Straja Țării. However, the first steps in the institutionalization of physical education had been taken a decade earlier.

The compulsory physical education for young people was introduced and regulated by the Law for the establishment of the House of People's Culture (November 3, 1921), updated by the Law for Physical Education of June 17, 1923. The organization of physical education in schools and other institutions and associations was coordinated by Oficiul Național de Educație Fizică [the National Office of Physical Education] (ONEF), subordinated to the Ministry of Public Instruction, in collaboration with the Ministry of War and the Ministry of Health, Labor, and Social Welfare (art. 2) ${ }^{22}$. The institutional triad under which this body was created and the composition of the steering committee suggested the authorities' approach toward the functions and significance of physical education for the future of the nation. Prince Carol, at that time, the successor to the throne of Romania, was the honorary chairman of this committee (1923 Law, art. 7). The National Institute of Physical Education (1923 Law, art. 16) was founded to train the staff in charge of implementing the policy of health through physical activity. The support of the Royal House for youth and physical education was also manifested through its involvement in the creation of the Scouts and the Christian youth organizations. Sports and outdoor activities were practiced by the young offspring of the royal family, but also by Queen Marie, famous for her passion for riding. The initial forms of organization of school sports associations are attributed to the initiative of young Prince Carol, around 1908. These were followed by the creation, in 1912, of a federation of sports associations and clubs (Federația Societăților de Sport din România [The Federation of Sports Societies in Romania]) ${ }^{23}$. Two decades later, Straja Țării appeared as a follow up of these projects, although evolving under the influence of the king's political agenda.

Physical education was a fundamental component of the doctrine of integral education, which emphasized the failure of purely intellectual training and proposed the educational formation of young people through morality, religion, and physical activity. This theory was also promoted by the schooling legisla-

sical education); in Portugal - the Acção Escolar Vanguarda (focused on nationalism, and the moral and physical development of youth); in the Soviet Union - the Young Pioneers etc.

${ }^{22}$ In 1929, ONEF was reorganized, being subordinated only to the Ministry of Health and Social Welfare, according to Legea educației fizice, Monitorul Oficial, Part I, no. 196, 4 September 1929. The law also stipulated the creation of Uniunea Federațiilor Sportive din România (UFSR) [the Union of Sports Federations in Romania].

${ }^{23}$ Constantin F. Nicolescu, Pagini uitate din istoria educației fizice (Bucharest: Editura Enciclopedică, 2014), 29-30. 
tion in force at the time, though schools didn't manage to generate an effective pedagogical model along these lines. Străjeria took over this desideratum, controlling the free time of young people and redirecting them ideally away from radical youth movements. The ideologues of Straja Țării emphasized that "the impulse of the youth to act is so strong that, if it is not allowed to work for good, it works for evil"; at the same time, in their view, the passivity of less temperamental youths became useless, as long as they were not guided toward constructive, social action ${ }^{24}$.

Therefore, the instrumentalization of the body through physical education and sports had multiple functions, aiming not only at a healthy personal development but also at reclaiming the energy of youth, otherwise wasted in harmful directions. Disciplining the body was the path to national regeneration. The basic legislation on sentinel training included some sketchy references to this aspect. The concern for the young body substantiated and legitimized the establishment of the OETR ${ }^{25}$. The Decree-Law of 1937, according to which Straja Țării became an autonomous institution, declared the new type of education to be mandatory, including its physical component (1937 Decree, art. 1). At the organizational level, sports were represented in the leadership of the OETR by the President of the Union of Sports Federations in Romania (OETR Law, art. $2)^{26}$. In collaboration with the Union, the OETR aimed to encourage practicing sports, though not the competitive element (OETR Regulation, art. 42), which would have countered the non-individualistic spirit it tried to inoculate into young people. Though the legislation lacked further details in this regard, propaganda pamphlets and doctrinal works developed this fundamental dimension of Straja Țării's activity. Based on these sources, the following pages will discuss some of the values attached to the social control of the young people by using physical education, including inculcating morality and obedience (a), reconnecting to nature / outdoor areas (b), and the revival of the nation (c).

(a) The ultimate goal of physical education was restoring the morality of the young. The post-war period had left a powerful impact on society, especially on the young generation, blamed for succumbing to immorality. Teachers and pedagogues thought that the youth had lost any guiding principles, that it suffered from destructive individualism, excessive materialism, and

\footnotetext{
${ }^{24}$ Ștefan Șoimescu, Doctrină, metodă sau curent de viață? (Bucharest: s.n., 1940), 14.

25 "[...] for the moral, national, and physical education of young people of both sexes up to the age of 18 " (OETR Law, art. 1).

${ }^{26}$ Subsequently, Straja took over the leadership of UFSR, of the sports federations and associations, appointing their presidents and half of the members of the management committees. (1937 Decree, art. 4).
} 
that it displayed a propensity for radicalization and violence. The economic crisis of the early 1930s exacerbated this perceived decline, and the youth's prospects seemed disoriented. The increasingly frequent acts of delinquency among the younger generation were associated with the excessive politicization of young people and their growing attachment to extremist movements. The Christian youth became more and more attracted to the radical anti-systemic organization, the Legionary Movement, with high schools functioning as recruitment sites ${ }^{27}$. In the winter of 1933-1934, certain actions involving young people of different ages sparked a public outcry. Prime Minister I.G. Duca was killed in December 1933 by a group of young legionnaires on the platform of the Sinaia train station. Two months later, three high school students in Bucharest killed a member of the Chamber of Deputies during a burglary ${ }^{28}$. The latter case spurred and accelerated the official implementation of the first measures involving severe controls in schools and organizations, as well as the creation of the OETR.

Sports promoters linked these violent incidents to the lack of a controlled channeling of youth energies. According to officer Constantin F. Nicolescu, a teacher in the field of military education, the discipline of sports would have accustomed the young to obedience and to the need to follow rules. In his opinion, sports should have held a prominent place in the activity of the school youth, because, "if these young people had taken up sports, they would not have had time to think about murder" 29 . At the same time, Nicolescu put the blame for this situation on the deficiencies of the sports infrastructure in the early 1930s: the lack of a recreational sports park, the discouragement of young people to participate in sports competitions, the excesses of sports shows ${ }^{30}$.

A similar position was held by Ștefan Șoimescu, a professor and publicist, as well as a member of the Superior Committee and the Standing Committee of Straja Țării. He was perceived as the main ideologue of the sentinels, but also as a creator of the king's personality cult. During the royal dictatorship, his writings framed Carol's actions regarding youth in terms of a social and pedagogical doctrine aiming at the revival of the new generation ${ }^{31}$. Şoimescu legitimized

${ }^{27}$ Roland Clark, Holy Legionary Youth. Fascist Activism in Interwar Romania (Ithaca, NY \& London: Cornell University Press, 2015); Anca Filipovici, “The Youth of the Unified Nation: Social Control and Discipline in Romanian Interwar High Schools”, New Europe College, Ştefan Odobleja Program Yearbook 2018-2019 (in print): 137-164.

28 „Prinderea asasinilor lui Eusebiu Popovici”, Dimineața, no. 9807 (18 April 1934): 1.

${ }^{29}$ Nicolescu, Pagini uitate, 203.

${ }^{30}$ Nicolescu, Pagini uitate, 204.

${ }^{31}$ Ștefan Șoimescu, Pe drumul rềnoirii (Bucharest: Bucovina I.E. Torouțiu, 1939), 6. 
and defended the king's political decisions through his theories and arguments, showing that, within the purported conflict between generations, Carol took the side of the youth, continuing the work he had started in the scouting movement ${ }^{32}$. Straja T,ării was to change the individualistic temperament of the youngsters and to inspire them with joy and exuberance, which would amount to remarkable results on the moral and national-ethnic terrain: "if we want a Romanian character, we must also aspire to a Romanian temperament"33. Physical education through gymnastics certainly responded to the need for bodily health. However, the Straja leaders believed that, unlike the limited approach of the school, gymnastics harmonized the body with morality and the spiritual dimension: "the educational ideal of the sentinel is the harmonious and fully developed man, citizen and soldier, member of a family and a free nation, faithful to the King". The tools necessary for achieving this ideal included exercise, hygiene, work, freedom, order, discipline, and healthy outdoor activities ${ }^{34}$.

(b) Discussing the limits and deficiencies of the school, Șoimescu concluded: "[...] the school no longer responded to the call of life. Literally and figuratively, the children lacked air, sun, movement, joy" ${ }^{35}$. It should be remembered, however, that in the last decades of the $19^{\text {th }}$ century, school architecture had undergone a reforming shift. School construction policies began to consider the imperatives of modernization, with buildings designed in compliance with contemporary aesthetic and hygiene standard ${ }^{36}$. The introduction of gymnastics in the curriculum also involved the creation of large and well-ventilated gym halls. But, as in-depth research of the topic shows, the application of this new policy only had an impact on secondary schools, and in some cases, on urban primary schools. These projects also conceived the schoolyard as a remote recreational space ${ }^{37}$. However, the students still spent most of their time sitting at rigid school desks. In the second half of the $19^{\text {th }}$ century, educators were already promoting the "Fröbelian games," to be practiced every 20-30 minutes to remedy the effects of the time students spent sitting, while "their bodies are tortured" 38 . The new buildings failed to meet the needs of the entire school

32 Șoimescu, Pe drumul reînoirii, 9.

${ }^{33}$ Şoimescu, Pe drumul reînoirii, 14.

${ }^{34}$ Şoimescu, Pe drumul reînoirii, 62-63

${ }^{35}$ Șoimescu, Doctrină...?, 6.

${ }^{36}$ Ramona Caramelea, „Spațiu fizic și spațiu social: arhitectura școlară în România în a doua jumătate a secolului al XIX-lea”, Archiva Moldaviae. Studii de istorie socială. Noi perspective, eds. Constantin Iordachi, Alin Ciupală, Supliment I (2014): 100.

${ }^{37}$ Caramelea, „Spațiu fizic și spațiu social,” 103.

${ }^{38}$ I.P. Florantin, Recreațiuni fröbeliane pentru tinerime în școală și familie (Iași: Editura Librăriei Școlelor Frații Șaraga, 1887), 1. 
population. After the war, the building offensive was resumed by Minister C. Angelescu, but the projects only sporadically met the requirements of the educational ideal. In rural areas, improvised school spaces remained in use. These buildings were often crowded, dimly lit, and unventilated.

From a gender perspective, this reconnection to nature was a display of masculinity $^{39}$ for boys. Scouting and Straja T,ării were conceived as gendered institutions. The training for girls aimed mainly at preparing young women for becoming mothers and housewives, according to the traditional distribution of roles. The masculinization of the boys through scouting as a means to counter their feminization by the school environment was a theory applied to the Anglo-Saxon environment at the crossroads of the $19^{\text {th }}$ and $20^{\text {th }}$ century when the expansion of public secondary education took place. In patriarchal societies, in which female emancipation progressed slowly, the feminization of the educational environment was linked to the increase in the number of girls in gymnasiums and high schools. Furthermore, female teachers emerged as a result of the access of girls to teachers' schools and universities. Even the imposition of school obedience through the passivity required while sitting at school desks was assimilated to the cultural construct of femininity ${ }^{40}$. As research shows, the reconnection of the boys with "manhood", through sports activities and the difficult challenges of adapting to the natural environment, accompanied by paramilitary training, were viewed by the creators of scouting as having strengthened the traditional hierarchies and gender roles ${ }^{41}$. Thus, training and discipline programs with specific designs for boys and girls were meant to produce "gendered bodies".

Releasing the body from the constraints of the school furniture was not only a desideratum for healthy development but also a form of social integration. The school was perceived as an artificial community, based on the relationship between each student and the teacher, while Straja Țării intended to become an organic community, where each youngster had a social responsibility to the whole community ${ }^{42}$.

${ }^{39}$ Masculinity as a relational concept - which implies individual difference and personal agency - is defined by the essentialist perspectives in terms of action and power, in opposition to passivity and femininity. See, e.g., R.W. Connell, Masculinities, 2nd edition (Berkeley: University of California Press, 2005), 68. According to a more complex approach, masculinity represents a social construct, a dynamic process of configuring practice within gender relations. See, e.g., Connell, The Men and the Boys, 29.

${ }^{40}$ Jeffrey P. Hantover, "The Boy Scouts and the Validation of Masculinity”, Journal of Social Issues, vol. 34, no. 1 (1978): 187, https://doi.org/10.1111/j.1540-4560.1978.tb02548.x.

${ }^{41}$ Hantover, "The Boy Scouts," 187.

${ }^{42}$ Iosif Gabrea, Școala și străjeria în pregătirea tineretului (Bucharest: Bucovina I.E. Torouțiu, 1938), 13. 
(c) From this perspective, the revival of the younger generation was equivalent to the revival of the nation ${ }^{43}$. The direct link between the health of the individual and the vigor of the nation through state intervention had been proclaimed by eugenic theories since the $19^{\text {th }}$ century $^{44}$. In Romania, almost a decade before the appearance of Straja, the university professor from Cluj Iuliu Hațieganu had developed a eugenic and biopolitical program within the ASTRA organization ${ }^{45}$, through the subsection of physical and moral education, which aimed to improve the health of the Romanian people in Transylvania. Physical education instructors, together with the intellectuals of the villages, were to train and guide the population towards a healthy life, correcting their pernicious daily habits linked to hygiene, nutrition, and the effects of overwork in agriculture ${ }^{46}$. The promotion of physical education as a matter of national interest was also supported by Col. Virgil I. Bădulescu, director of the Office and the National Institute of Physical Education. In a conference held at an ASTRA meeting, he emphasized the importance of physical education for preparing young people for national defense: "In peacetime, we tend to raise our children like gentle lambs [...] then suddenly, in times of war, we break the balance and ask the lambs to become lions" ${ }^{\prime \prime 7}$.

The physical education subsection was transformed in 1928 into the organization Şoimii Carpaților [Carpathian Hawks], a regional variant of the Czechoslovak Sokols, with statutes elaborated by Professors Iuliu Moldovan and Atanasie Popa. The new organization was institutionalized in 1930, in Cluj, under the leadership of Hațieganu ${ }^{48}$. Adult youths between the ages of 18 and 35 became members of this association. They were called şoimani (sic!) [hawks]. The association placed a special emphasis on physical education, in the core cities of the region: Sibiu, Brașov, Cluj, and Sighet. Starting from 1932, it was gradually extended to the villages, where it achieved greater success than in the cities. Under the motto "All for the good of the nation", Șoimii Carpaților

${ }^{43}$ See, for instance, Irina Livezeanu, Cultural Politics in Greater Romania: Regionalism, Nation Building, and Ethnic Struggle, 1918-1930 (Ithaca, N. Y.: Cornell University Press, 1995); Clark, Holy legionary youth.

${ }^{44}$ Marius Turda, Eugenism și modernitate. Națiune, rasă și biopolitică în Europa (1870-1950) (Iași: Polirom, 2014), 73.

45 The Transylvanian Association for Romanian Literature and the Culture of the Romanian People (ASTRA) had been created in Sibiu in 1861 and was the main group that strove for the political and cultural emancipation of the Romanians from Transylvania.

${ }^{46}$ Popa, Sport și educație fizică, 126.

${ }^{47}$ Virgil I. Bădulescu, Educația fizică, o problemă națională (Sibiu: Astra, 1927), 10.

${ }^{48}$ Dragoș Petrescu, Daniela Petrescu, „Organizația Șoimii Carpaților în perioada interbelică”, Carpica, no. 32 (2003): 187. 
promoted the work for the nation's progress, along with the sentinels and the scouts ${ }^{49}$. However, the physical education of the "hawks" was based exclusively on Romanian biopolitical and ethnic principles: Their education was tailored according to the individual and the national biological doctrine. It aspired to the physical-moral and intellectual prosperity of the individual and the nation by capitalizing on the physical, moral, and intellectual forces and directing them towards the service of the community. [...] The physical and moral vigor ensures the eternity of the nation $[. .$.$] - discipline is the force that transforms$ freedom into power" ${ }^{50}$.

\section{Not that strong, nor that healthy. Young bodies, hygiene, and public health in Romania}

The concerns for hygiene and public health have been increasingly obvious in Europe since the end of the $18^{\text {th }}$ century, when the first systematic actions of public health research took place, along with growing state intervention in matters related to the death and the birth rate, fertility, and the eradication of social diseases. During the next century, the standardization of public hygiene, various models of a social security system, and the concern for improving the quality of the living environment (urban-industrial planning) constituted the main fields of intervention of a new form of technology of power, called biopoli$\operatorname{tics}^{51}$. However, unlike discipline, biopolitics did not aim at individual control, supervision and training but at establishing a set of mechanisms for collective regulation and optimization, to be carried out over the long term. Power was exercised in this complex process through its regularizing ability to intervene through assisting certain people to live while allowing others to $\mathrm{die}^{52}$.

In the $18^{\text {th }}$ century, the Romanian Principalities also introduced the first norms for a permanent organization of hospital institutions and the management of hygiene and public health. The Organic Regulations (1831/32) and other modern laws were gradually adopted throughout the $19^{\text {th }}$ century, culminating in more complex legislation concerning curative and preventive medicine $^{53}$. The law of 1910 - the work of Dr Ion Cantacuzino ${ }^{54}-$ symbol-

\footnotetext{
${ }^{49}$ Iuliu Hațieganu, „Şoimii Carpaților”, Transilvania, no. 4 (July-August 1936): 232.

${ }^{50}$ Hațieganu, „Șoimii Carpaților”, 233-234.

${ }^{51}$ Michel Foucault, „Trebuie să apărăm societatea”. Cursuri ținute la Collège de France (19751976), 2nd edition, trans. Bogdan Ghiu (Cluj-Napoca: Idea Design \& Print, 2009), 192-193.

${ }^{52}$ Foucault, „Trebuie să apărăm societatea”, 195.

${ }^{53}$ Alina Ioana Șuta, Oana Mihaela Tămaș, Alin Ciupală, Constantin Bărbulescu, Vlad Popovici, coord., Legislația sanitară în România modernă (1874-1910) (Cluj-Napoca: Presa Universitară Clujeană, 2009).

${ }^{54}$ Legea sanitară din 1910, Monitorul Oficial, Part I, no. 211, 20 December 1910.
} 
ized certain progress in introducing elements of modern medical approaches and remained in force for the next twenty years. However, material difficulties and staff shortages led to unsatisfactory results in its application, especially in rural areas ${ }^{55}$. This also had an impact on the situation of the youth of all ages.

In 1929, the hygienist doctor Gheorghe Banu ${ }^{56}$ discussed the relationship between school attendance, young people's health, and delinquency, based on data collected for the 1920s and on the results of a survey conducted at schools in Mănăștur, Cluj County. Banu pointed out that poor school attendance was caused by three factors. Almost 5\% of students of all grades were affected by physical problems, which altered the child's personality and psychology. Most of these issues were the result of hereditary factors ${ }^{57}$. Even more students suffered from chronic diseases (especially tuberculosis (25.5\%)) and other transient, recurrent diseases ${ }^{58}$ : eye diseases - myopia ( $53.2 \%$ girls, $46.8 \%$ boys), ENT diseases (40\%), dental problems (76.8\%), pediculosis (79\% girls, $24 \%$ boys), spinal issues - scoliosis (20\%), heart diseases (2\%). Finally, the social factors of non-attendance had the largest share in the country where $80 \%$ of the population lived in rural areas. Banu identified parental ignorance, poverty, poor hygiene conditions, and malnutrition as the main problems. The considerable distance from the school and the exploitation of child labor in agriculture also led to poor attendance. $48 \%$ of the students lived in inappropriate conditions, sharing the same room, and sometimes even the same bed, with several other family members. For $50 \%$ of the children, the diet was irregular and insufficient ${ }^{59}$. The solutions envisaged in this case study aimed at fining students for not attending primary instruction, but also at establishing medical supervision in schools and increasing social protection measures ${ }^{60}$.

${ }^{55}$ Virgiliu Leonte, Sănătatea publică în România (Bucharest: Imprimeria Naţională, 1938), 72. Estimative data in 1938 indicated 9000 doctors in urban areas (1 doctor per 390 people) and only 1000 doctors in villages (1 doctor per 15,500 people), in Leonte, Sănătatea publică, 74. Specialists suggested some solutions for this situation. These included the reform of the medical system, encouraging practitioners to reside in villages, and granting them a temporary state allowance, coupled with the training of hygienists, to be focused exclusively on hygiene and preventive medicine, in Leonte, Sănătatea publică, 84.

56 The future Minister of Health and Social Care in the Goga-Cuza government (December 29, 1937 - February 10, 1938).

${ }^{57}$ D.G. Banu, Rapport sur la non-fréquentation scolaire en Roumanie, Extrait du Bulletin International de la Protection de l'Enfance, no. 85 (October 1929), 5.

${ }^{58}$ Banu, Rapport, 6-7.

${ }^{59}$ Banu, Rapport, 13-15.

${ }^{60}$ Banu, Rapport, 18-21. 
The health of schoolchildren was still far from being satisfactory and mirrored, in fact, the general state of the population's health. In the 1920s, eugenics-influenced doctors claimed that the dangers that "threaten and wreak havoc in schools are largely medical". In this context, eugenics would have been essential, because it would have ensured "the strengthening of the body through physical and hygienic education”. The responsibility fell to the school doctor - "the second parent, in front of whom no student should have anything to hide" - because "the school has the great mission to give tomorrow's society perfect bodies" ${ }^{1}$.

A new step towards public health reform was made by the Sanitary and Care Law of July 14, 1930, which remained in force, with several amendments, until the $1940 \mathrm{~s}^{62}$. Social Welfare Establishments, with their special sections and institutions for various vulnerable categories, coordinated the actions of the social assistance for schoolchildren until the age of adolescence (1930 Sanitary Law with amendments, art. 138). At the same time, the law provided for specialized sanitary supervision for primary and secondary school students in school dispensaries, school canteens, open-air schools, prevention centers, holiday camps ${ }^{63}$, and other special school institutions (1930 Sanitary Law, art. 435). School hygiene was a distinct policy direction. It was promoted through a program established by the Ministry of Education in collaboration with the Ministry of Labor, Health and Social Welfare, which involved the direct contribution of school doctors (1930 Sanitary Law, art. 436), but also the creation of career guidance offices (1930 Sanitary Law, art. 437). Social assistance had to be supplemented by private initiative, through charitable societies concerned with the protection of youth (1930 Sanitary Law, art. 458). But this law was also applied with only partial success. The reality, including the situation of the youth, was generally inconsistent with the desiderata of the regulations. There are numerous school surveys relevant in this regard. Many of them represented the research work of the members of the Sociological School in Bucharest.

${ }^{61}$ Dominic Stanca, O anchetă sanitară la un liceu (Cluj: Editura Revistei Societatea de Mâine, 1924), 4.

${ }^{62}$ Legea sanitară și de ocrotire din 22 iunie 1935, cu toate modificările la zi, ediția a IV-a (Bucharest: Editura Socec \& Co., 1941). In its initial form, the law was promulgated by the Royal Decree no. 2515 of 1930, Monitorul Oficial, Part I, no. 154, 14 July 1930.

${ }^{63}$ The number of summer camps in the mountains and at the seaside, created by the Ministry of Health, local authorities, and private institutions, increased considerably in the late 1930s. 75 summer colonies operated in 1937 for children with various diseases, and 3 preventive medicine facilities were opened for children prone to tuberculosis. In Enciclopedia României, vol. 1 (1938), 530-531. 
Medical sociology research ${ }^{64}$ often refers to the school surveys published in 1937, under the coordination of doctors G. Banu and Anatole Cressin, who correlated the situation of the youth with its living standards. The first step was to assess the physical condition and dietary practices of schoolchildren from various social backgrounds enrolled in the schools of Bucharest and Ialomița County. The results showed that they developed most diseases and health conditions (48.4\% in rural areas and $42.7 .4 \%$ in urban areas) at the age of puberty (13-14). While researching nutrition, the survey also targeted more than 132,000 students in Bukovina. Only $23.8 \%$ of Bukovinian students ate 4-5 times a day, while $36.6 \%$ ate meat once a week, and $73.5 \%$ ate polenta at all meals. Estimating the situation at the national level, the doctors indicated that $24-34 \%$ of students were well fed, $36-62 \%$ were malnourished, and another $14-30 \%$ were poorly fed ${ }^{65}$. Ultimately, the investigation sounded the alarm concerning the state of affairs in schools: "we must not only take care of the school walls, but we must also take care of the human material". The state had to watch over the normal development of the youth "if it does not want this half-hungry and halfgrown youth to slip further towards the slope of degeneration" ${ }^{36}$.

Another survey coordinated in 1932-1936 by Banu and Cressin, involving 827 students of King Carol I Commercial School in Bucharest, analyzed the robustness index in correlation with the origin and profession of the father. The survey concluded that the most robust students were children of peasants. As expected, only relatively wealthy peasants could afford to financially support their children in secondary schools. At the same time, the malnourished students were usually children of factory workers and craftsmen ${ }^{67}$. The authors also pointed out that the creation of public jobs for school doctors in all secondary schools existed only on paper, as their duties were not precisely defined and no auxiliary staff was provided to assist them. Due to budgetary difficulties, this provision was only applied to a small extent ${ }^{68}$.

In addition to the issue of harmonious development through physical education and hygiene, another aspect related to the young people's trajectory on

\footnotetext{
${ }^{64}$ See, e.g., Bogdan Bucur, "Population Health in Interwar Romania Reflected in the Sociological School of Bucharest's Research and Publication”, in Health and the Media. Essays on the Effects of Mass Communication, eds., Valentina Marinescu, Bianca Mitu (Jefferson, North Carolina: McFarland \& Company, 2016), 215-240.

${ }^{65}$ Data extracted from Anatole Cressin, Starea fizică și alimentația școlarilor în România, extras din Sociologie românească, no. 5-6 (May-June 1937).

${ }^{66}$ Cressin, Starea fizică, 4.

${ }^{67}$ Anatole Cressin, Starea fizică și socială a elevilor școalei comerciale „Regele Carol I” din București. Studiu statistic și de igienă școlară, extras din Revista de igienă socială, no. 3 (1937).

${ }^{68}$ Cressin, Starea fizică și socială, 6.
} 
the verge of adolescence - sexual life - became subject to adult control. Doctors were encouraged to guide the youth regarding a topic that was considered taboo and dangerous: masturbation and premature sexual intercourse generating venereal diseases ${ }^{69}$. Since the previous century, the medical and educational literature had been campaigning to preserve the innocence of children and young people, insisting on the fact that non-adult sexuality was unnatural. In-depth research of the sources produced in the $19^{\text {th }}$ century shows that the youngsters' sin of masturbation, especially when practiced in school, generated a genuine moral panic among adults, which was amplified by pseudo-medical opinions that proposed a list of diseases presumably caused by such habits ${ }^{70}$. With too few supporters of sex education for young people, the prevention of what was considered abnormal involved medical treatments, special diets, but also rigorous hygiene and physical education ${ }^{71}$.

Disciplining sexuality aimed not only at having a general effect on the body but also at implementing biopolitical ideals. Sexual debauchery was believed to lead to social degeneration, with a long-term collective effect ${ }^{72}$. These elements became principles of the eugenic foundations of education, coupled with other specific requirements, such as periodic medical controls and treatment of diseases, ensuring the best possible learning spaces, providing baths (showers) for body hygiene etc. All this should have produced a healthy young generation, free from the old deficiencies of the school that created weak and exhausted people. In the 1920s, the Scout association, the forerunner of Straja Țării, was invoked as a model organization adhering to hygienic principles: "being the best platform for the education of the school masses, scouting responds to the supreme desire for hygiene". The outdoor release of energies was meant to ensure not only an enduring success in the fight against the social diseases of the time - tuberculosis and bodily weakness - but also against the "hybrid vice of masturbation"73. And yet, this vice did not cause the greatest fears among educators. Something else was viewed as much scarier. Adolescents were seen by pedagogues and doctors as part of a generation plagued by nervous breakdowns. Confronted with the crises of coming of age and with adult pressures, teenagers sometimes resorted to the extreme gesture of suicide.

${ }^{69}$ Stanca, $O$ anchetă, 9.

${ }^{70}$ Ramona Caramelea, „În etatea critică a amorului. Copilărie, adolescență, sexualitate și educație publică (deceniile șase-opt ale secolului al XIX-lea)”, in Sexualitate și discurs politicoreligios în societatea românească premodernă, ed. Constanța Vintilă-Ghițulescu (Iași: Editura Universității Al. I. Cuza, 2016), 302.

${ }^{71}$ Caramelea, „În etatea critică a amorului”, 303.

${ }^{72}$ Foucault, „Trebuie să apărăm societatea”, 198.

${ }^{73}$ Stanca, O anchetă, 10-11. 
The Straja ideologues and the school pedagogues drew constant attention to the increasingly common phenomenon of suicide among school-age adolescents: "due to a strong disappointment, to a worse grade, to a failed exam, or to a rebuke, the poor youngsters threw away the gift of life like an unbearable burden". The responsibility for this situation presumably fell on the shoulders of the immoral society, the disoriented family, and the school emphasizing "exclusively and excessively intellectualist" preoccupations, which resulted in training an intellectual proletariat ${ }^{74}$. As the cases in the archives show, many suicides of teenagers occurred also on a depressive background and for extracurricular reasons, related to family relationships or emotional failures, but also due to poverty and lack of career perspectives.

A certain typology of suicidal acts of high school students can be found in the archival documents generated by the Ministry of Education during the interwar period. The case files contain three perspectives: the accusatory act of the parents/ the victim against the school; the investigation of the school inspectors and the resolution of the ministry; the press reports. Some resounding cases highlight the problematic relationship between the school and the student, but also the magnitude of mental challenges, at an age of extremes, in a society beset by various crises. In 1924, Gheorghe Buciumeanu, a student at Andrei Șaguna High School in Brașov, committed suicide by poisoning. His father accused the director of the boarding school, Professor I. Hangu, of subjecting his son to physical and mental persecution ${ }^{75}$. The same year, in Tulcea, Ștefan Bogatu threw himself from the top of a cliff following a nervous breakdown caused by the examination in mathematics conducted by professor Motomancea ${ }^{76}$. Traian Botlovan, a student from Caransebeș, shot himself in 1932 on the grounds of a week-long expulsion sentence, following complaints addressed to the high school principal, after a sleigh incident ${ }^{77}$. Nicolae Gheorghe, a high school student from Pitești, committed suicide also due to his expulsion from school, after being punished for trying to deceive the teachers' vigilance when caught without his enrollment number on the uniform's sleeve ${ }^{78}$. Suicide also claimed female victims. Eugenia Munteanu, a student at the Girls' High School in Galați, ended her life by poisoning herself in 1934, following a love affair with a high school student. The harmful psychological pressure was exerted upon her by her mother and by the teacher who had found out about the relationship ${ }^{79}$.

\footnotetext{
${ }^{74}$ Șoimescu, Doctrină...?, 5.

75 ANIC, Fund The Ministry of Education, file 357/1924, 25.

${ }^{76}$ ANIC, Fund The Ministry of Education, file 358/1924, 100.

${ }^{77}$ ANIC, Fund The Ministry of Education, file 308/1932, 128.

${ }^{78}$ ANIC, Fund The Ministry of Education, file 437/1934, 210.

${ }^{79}$ ANIC, Fund The Ministry of Education, file 382/1933, 25.
} 
Juvenile suicides had become an alarming phenomenon that required the authorities' intervention, including action by Straja Țării. Teachers' extreme requirements and even violence usually determined the unfortunate decision, even if some pedagogues, such as the inspector investigating the case at the A. Şaguna boarding school, believed that "severity is often, and especially nowadays, a necessity for educators". Moreover, "corporal punishments [are] used and can be useful - in many boarding schools, without causing suicide" ${ }^{80}$. In some situations, tensions at school overlapped with a lack of communication with the family and other unbearable pressures. As the victims' descriptions show, nervous breakdowns were a feature of sensitive, apathetic natures. The suicidal acts were not spontaneous, but instead meticulously prepared. All the above-mentioned wrote letters to family and friends as a farewell, but also to justify their action and to denounce those carrying the blame: "Dear Father, my dear brothers and relatives, I did this only because of the school", wrote student Buciumeanu in the introduction to his emotional letter ${ }^{81}$. The farewell note of student Bogatu had been found by his mother before his committing suicide, but this did not prevent him from carrying out his intention ${ }^{82}$. Traian Botlovan confessed that "because I cannot bear this unfair punishment - as I swear to my innocence - I asked for my high school documents, deciding to shoot myself and thus put an end to my life" ${ }^{83}$. Eugenia Munteanu from Galați wrote to her mother: "You were too cruel, well, yes, too cruel [...] And too distant" These testimonies reflect the high pressure exerted by the school on youngsters, which was sometimes amplified by the parents.

Schools denied any responsibility, shifting the blame exclusively onto the parents of the victims - and the victims themselves. In the above-mentioned suicide cases, they usually invoked external causes: the depressive mood of the victims $^{85}$; the lack of parental action ${ }^{86}$; or even the fact that "death is due to suicide, for which no one can be held responsible" ${ }^{87}$. Schools usually defended the teachers. Some notes drafted by the teachers' superiors dealt superficially with the situation. Thus, the management of A. S,aguna High School stated dryly: "We have the honor to kindly instruct Mr I. Hangu, Director of the Boarding

\footnotetext{
${ }^{80}$ ANIC, Fund The Ministry of Education, file 357/1924, 27.

${ }^{81}$ ANIC, Fund The Ministry of Education, file 357/1924, 33.

${ }^{82}$ ANIC, Fund The Ministry of Education, file 358/1924, 100.

${ }^{83}$ ANIC, Fund The Ministry of Education, file 308/1932, 133.

${ }^{84}$ ANIC, Fund The Ministry of Education, file 382/1933, 44.

${ }^{85}$ ANIC, Fund The Ministry of Education, file 357/1924, 27.

${ }^{86}$ ANIC, Fund The Ministry of Education, file 358/1924, 100.

${ }^{87}$ ANIC, Fund The Ministry of Education, file 308/1932, 129.
} 
School, not to use corporal punishment"88. As regarded Professor Motomancea, the school committee declared that any accusations against him were pure slander ${ }^{89}$. The act of Eugenia Munteanu, who had succumbed under the psychological pressures of her teacher, was explained as the exclusive result of the "mother's reprimands" 90 . The conclusion of the investigations submitted by the inspectors generally declared the cases closed.

However, closing the case did not solve the purported fundamental problem, which pedagogues and educational analysts always brought back to the center of the debate: the increasingly sensitive and depressed youth was not only a sad image in itself but also a danger for the future of the nation. The deficiencies of the dominant pedagogical model were well captured by the local newspaper from Tulcea, which wrote about the case of Ștefan Bogatu: "an outdated and pointless education system, which today has no further reason to function. To decide so easily on a student's situation, without taking into account his state of mind, his temperament, his background, and his school activity, means to push him towards acts of despair"91.

\section{Sentinels in good shape}

Taking over a reportedly declining youth, Straja Țării campaigned for the health of the young generation and took on the role of mentor over the mental and physical development of the youthful bodies. "The movement aroused by the sentinels has aimed to regenerate the country by regenerating children. It has promoted health against disease, and order against moral chaos", the promoters of Straja asserted ${ }^{92}$. At its inception, the OETR provided for the possibility of free medical treatment for young people enrolled in Straja Țării, based on the recommendation of the organization, as well as mandatory medical check-ups twice a year (OETR Regulation, art. 57). However, I have not found any evidence of such controls so far.

Given the increasing importance of the festivities of June 8, marking the Day of Youth and the Restoration, the authorities decided which sentinels were allowed to attend based on health criteria. School doctors had to recruit students participating in parades only among those with a good physical condition. This can be interpreted as a form of eugenic selection meant to impress the audience - the large public but also foreign officials - with the display of

\footnotetext{
${ }^{88}$ ANIC, Fund The Ministry of Education, file 357/1924, 26.

${ }^{89}$ ANIC, Fund The Ministry of Education, file 358/1924, 109.

${ }^{90}$ ANIC, Fund The Ministry of Education, file 382/1933, 25.

91 „Dureri mute”, Curierul Tulcei, III, no. 92 (7 July 1924): 1.

${ }^{92}$ Șoimescu, Doctrină...?, 9.
} 
a healthy young generation. Those deemed unfit, with mental or convalescent problems were usually left at home ${ }^{93}$. Feeding the participants in the parades remained the responsibility of the parents: "The school doctors will inform the sentinels that they should eat before going to the demonstrations and that they should also take 2-3 pieces of sugar and a bagel to eat between 11-13"94.

This aspiration for remedying young people's health had scarcely any practical results. As early as March 1937, the General Sanitary Inspectorate of the OETR had initiated a unitary health plan, requesting the participation of school doctors ${ }^{95}$. The action had no concrete results, though. Straja Țării Law of 1938 reiterated, in theory, its responsibility regarding health issues. However, it only took on a passive role in the supervision of the nutrition practices and hygiene of the youth (1938 Law, art. 8). Meanwhile, the adult youth became involved in the social work programs for public benefit (1938 Law, art. 9). In March 1939, the rules for the collaboration between Straja Țării, the Ministry of National Education, the Social Service, and the PreMilitary Training established the obligation of the sentinel commanders to carry out social visits to individual families to investigate and trace the social reality ${ }^{96}$. However, in 1940 , Straja Țării still discovered that "there is a very high proportion of sentinels who suffer from various deformities of the spine or chest, as well as respiratory failure, conditions which cause disorders in their normal development". As a result, Straja set up "a voluntary gymnastics and orthopedics course"97. Straja interventions in the sentinel's health condition were therefore minimal, reflecting the fragile involvement of the state in the public health sphere.

A large-scale initiative in this regard took place in 1938, during the royal dictatorship when a so-called "health offensive" was initiated. This was a pilot project under the coordination of the Ministry of Health and Welfare and represented the first complex health campaign after 1918. Through its emphasis on public health and hygiene, the project is similar to another major social reformist initiative from the interwar period, namely, the monographic campaigns carried out in rural areas by the Sociological School of Bucharest, under the coordination of Professor Dimitrie Gusti. In the 1930s, these campaigns developed a series of health initiatives, which enlisted the participation of the Royal

\footnotetext{
${ }^{93}$ ANIC, Fund The Ministry of Education, file 571/1937, 195.

${ }^{94}$ ANIC, Fund The Ministry of Education, file 571/1937, 195.

${ }^{95}$ ANIC, Fund The Ministry of Education, file 571/1937, 139.

${ }^{96}$ ANIC, Fund The Ministry of Education, file 822/1939, 106.

${ }^{97}$ ANIC, Fund The Ministry of Education, file 739/1940, 22.
} 
Student Teams (1934-1938) and the Social Service (1938-1939), supported by the Ministry of Health ${ }^{98}$.

In the summer of 1938, this ministry coordinated a large-scale campaign in villages and towns, which aimed to elaborate a full sanitary record of the country. Among its goals was health improvement, which should have been achieved by organizing and supplementing the local medical staff, by measures to combat contagious and social diseases, by hygiene interventions and sanitation projects, and by other social protection and educational measures intended for different social categories. The survey-based plan and methodology were complex and ambitious, but they would have required a consistent budget, significant materials and a trained staff, coupled with a long-term implementation strategy to achieve these goals. The course of events and the start of the war interrupted the application of the project. Yet, the four published volumes detailing the conduct of the campaign constitute an important source for assessing the state of public health at the grassroots level, with peculiarities depending on the regions and the urban or rural environment ${ }^{99}$.

The health campaigns of August-September 1938 also aimed at intervening concerning the children and youth's health. The sanitary teams were supported by staff from various institutions and organizations, including Straja Țării commanders and sentinels mobilized for collective hygiene actions ${ }^{100}$. School hygiene was a distinct aspect of the campaigns and aimed at prioritizing the

${ }^{98}$ For a broader view on the voluntary campaigns, see the monographic study of Raluca Mușat, Sociologists and the Transformation of the Peasantry in Romania, 1925-1940, PhD Thesis (2011). The platform Cooperativa Gusti (http://www.cooperativag.ro/), initiated by Professor Zoltán Rostás, holds extensive materials on the activity of the Sociological School in Bucharest. In recent years, impressive works have been published on this topic by the researchers joining Cooperativa G.

${ }^{99}$ Some reports from the regional inspectorates show bleak images of stagnation. For instance, the General Sanitary Inspectorate of Iași emphasized that, in 1938, sanitation in urban areas was almost as bad as in villages: only $34 \%$ of homes had latrines, of which almost half were unsanitary; in almost all county capitals there were no sewers; in the suburbs, the manure was thrown directly onto the street; water was used from unhygienic wells; no Moldavian city had garbage processing services or an efficient slaughter service. Under these conditions, in Moldavian cities, epidemics of typhoid fever were constantly occurring. In: Ministerul Sănătății și Asistenței Sociale, Probleme și realizări, vol. 1 (Bucharest: Imprimeria Națională, 1939), 436-437.

${ }^{100}$ Ministerul Sănătății, Probleme și realizări, 15. The mobilized human resources involved over 2,000 doctors, supported by over 5,000 people from the auxiliary medical staff, the teams of the Royal Foundation, and the staff of the Cultural Society "ASTRA". They were joined by over 144,000 supporting staff, among them, 63,771 pre-military students and 35,210 sentinels. In Ministerul Sănătății, Probleme și realizări, 44. 
medical care of primary school students within the activity of urban and rural health services. A series of measures were to be implemented at the beginning of the school year (sanitary controls and interventions), followed by periodic evaluations. The medical staff was to treat the youngsters' diseases, place them at school desks according to their health condition, organize summer camps for treatment, evaluate their nutrition practices and monitor the accommodation conditions. However, without a rigorous budget, the methodology relied too little on effective intervention, rather emphasizing recommendations, instructions, and evaluation activities ${ }^{101}$. According to the health authorities, the medical care of the students had to become a question of national interest, since the school population represented almost a quarter of the country's entire population (i.e., 4,466,274 children aged 5-18). The lack of measures targeting the young generation would have had serious long-term consequences. The authorities were aware of the precarious state of students' health revealed by numerous school surveys. They thought that this was due to the poor performance of rural health workers and school doctors ${ }^{102}$. Furthermore, the state had a limited contribution to providing food or accommodation to students lacking resources in secondary education. It was clear that, without such supports, the evolution of the students' health would hardly improve ${ }^{103}$. At the initiative of Minister Marinescu, a fund for school canteens had been set up in $1938^{104}$, and an appeal had been launched to wealthy private persons to get involved in village

${ }^{101}$ Even if the periodical health assessments provided an up-to-date image of the situation, school infrastructure in some areas needed massive overhauls and investments. For example, according to a report of the Chișinău Sanitary Inspectorate, schools were housed in inappropriate premises; some were even without built floors, toilets, water vessels, or heating during the winter. Ministerul Sănătății, Probleme și realizări, 516.

102 Ministerul Sănătății, Probleme și realizări, vol. 2, 1145. However, a report referring to the city of Sibiu highlighted the politicization of the health officials and environment: "Until now, health services could only prosper if the doctor and the prefect or mayor were on the same political side or when there were friendly relations between the two sides", in Ministerul Sănătății, Probleme și realizări, vol. 3, 1492.

${ }^{103}$ Ministerul Sănătății, Probleme și realizări, vol. 1, 37-38. The minister of Health noted that social assistance was provided primarily by private charities, and that the achievements of the ministry were only in their initial stage. In terms of the current situation of school health and hygiene, the state had managed to improve the medical infrastructure, but the steps towards a general modernization of the health system were still insignificant. Ministerul Sănătății, Problemeși realizări, vol. I, 50.

${ }^{104}$ Similar initiatives, though ineffective, were launched by the ministers of Education during the 1930s as part of the reforms of primary education. See Petru Negură, "Compulsory Primary Education and State Building in Rural Bessarabia (1918-1940)", Journal of Romanian Studies, vol. 2, no. 2 (2020): 55. 
life through charities. The state admitted its helplessness: "Across the country, the assistance of children is so poor, despite all the benevolent interventions of a few persons, that our children have remained unprotected"105.

\section{Conclusions}

Being aware that controlling the country's youth allowed to achieve political goals, Carol II transformed Straja Țării into the main state institution that instrumentalized youth policies, competing with anti-establishment youth movements. Among the mechanisms developed for capturing the energy of young people and monitoring them before their reaching adulthood were physical education and the improvement of physical and mental health. Physical education within sentinel training was a fundamental component of the doctrine of integral education that aimed at reeducating the young based on the triad: morals - religion - physical activity. The physical activity involved multiple components, which aimed not only at fostering healthy development but also at cultivating loyalty to the king, building an organic community and especially at encouraging national regeneration by disciplining the body. Physical education should have spread morality through the useful direction it would have given to the dynamics of adolescence. The authorities viewed the social control exercised through Straja Țării as compensation for the limitations of the school system unable to manage juvenile energies. Subordinated directly to the king self-appointed as the Grand Sentinel, Straja expended its autonomy and dominated all youth structures, including primary and secondary schools. The introduction of the sentinel training in the school curriculum was a central stake, as most of the sentinel youth were students enrolled in the public or private education system. It was imperative because young people with an unhealthy lifestyle, lacking morals and discipline were considered a danger to the future of the state.

At the same time, prioritizing propaganda over social and health-related issues, the ideals of Straja did not produce the expected results. Public health had been a thorny issue for decades, especially in rural areas. The 1938 campaign, which also involved the sentinels, would probably have improved the health of the young people if it had been applied consistently in the long run. Dr N. Marinescu, the minister of Health, attributed the initiative of the "sanitary offensive" to King Carol II, presenting it as a project designed by an enlightened mind. Although the underlying reality was not new, the project was thus used for the royal cult of personality, which was fueled with everything deemed potentially

${ }^{105}$ Ministerul Sănătății, Probleme și realizări, vol. 2, 1147. 
beneficial: "A new consciousness awakens, a unanimous sense of defense boosts the will to raise the standard of living in our country" ${ }^{106}$. At the same time, the minister took the blame: "We have been too seduced by the value of the physical endurance of our people, a value which we have tried to turn into a label, and we have gone so far that we have even forgotten that this value must be taken care of, must be maintained and developed"107.

Straja T,ării wished for vigorous soldiers, for young healthy bodies similar to those of the young people depicted in the propaganda posters of Hitlerjugend in Germany or Opera Nazionale Balilla in Italy. Romanian sentinels were shown on the covers of propaganda brochures and magazines ${ }^{108}$ as strong, healthy youngsters, wearing their uniforms with the distinctive berets, scarves and belts, doing farmwork or marching or greeting King Carol II. Michael, Carol's son and heir apparent was commonly depicted as the model sentinel guarding the country. However, in the absence of concrete and effective state interventions, "Good health!" - the ideal of the sentinels - remained nothing more than a greeting formula ${ }^{109}$.

\section{Rezumat}

Acest articol analizează organizația de tineret Straja Țării, creată de regele Carol al II-lea în contextul tensiunilor sociale și politice din România anilor '30. Având ca scop major formarea loialității tineretului față de rege, Străjeria încerca să implementeze un sistem alternativ de educație integrală bazată pe valori morale, religiozitate, patriotism și pregătire fizică. Deși a activat pentru puțină vreme (1934-1940), Straja Țării a reprezentat una dintre principalele instituții de intervenție socială, cu autonomie proprie, mobilizând resurse umane şi financiare considerabile. A dezvoltat mecanisme și instrumente specifice pentru controlul tineretului, incluzând disciplina prin educație fizică ce ar fi trebuit să confere forță trupurilor tinere. Articolul analizează funcțiile multiple ale acestor mecanisme pe baza documentelor de arhivă, a legislației aferente și a anchetelor de sănătate desfășurate la acea vreme. Cercetarea urmărește trei nivele de analiză: reglementarea educației

\footnotetext{
${ }^{106}$ Ministerul Sănătății, Probleme și realizări, vol. 1, 40.

${ }^{107}$ Ministerul Sănătății, Probleme și realizări, vol. 1, 40.

${ }^{108}$ See, for instance, the illustrations and pictures in the sentinels' magazine De Strajă (Bucharest: 1937-1940).

${ }^{109}$ The Scouts' salute was taken over by the sentinels, according to the 1934 OETR Regulation, art. 41. Subsequently, a decision of the OETR in February 1937 informed the Ministry of Education about the obligation to use the greeting "Good health!" in school, on all occasions, and not just during the sentinels' program and activities. ANIC, Fund the Ministry of Education, file 571/1937, 41 .
} 
fizice și a sănătății publice în România interbelică (1); controlul social al corpului tinerilor prin Straja Țării (2); deficiențele de sănătate ale tinerei generații (3). Principalul argument al textului este acela că Straja a construit un prototip național supraevaluat al vitalității tineretului, fără a aborda eficient carențele și clivajele din cadrul unei națiuni doar relativ sănătoase.

Cuvinte-cheie: tineret, disciplină, educație fizică, sănătate publică, Straja Țării, biopolitică.

Filipovici, Anca, Romanian Institute for Research on National Minorities

(Cluj-Napoca).Email: anca.filipovici@yahoo.com 